\title{
Physical Anthropometry in Estimation of Stature: A Systematic Review
}

\section{Pinki Rai ${ }^{1}$, Ashima Das ${ }^{2}$, Ajay Kumar Agrawal ${ }^{3}$, Diksha Arora ${ }^{4}$}

Section: Healthcare

Sci. Journal Impact

Factor: 6.1 (2018)

ICV: 90.90 (2018)

(c) (i) (3)

Copyright@IJCRR
ThD Scholar, Department of Anatomy, SGT Medical College and Hospital, Gurugram, India; 'Associate Professor, Department of Anatomy, SHKM Government Medical College, Nuh, Haryana, India; ${ }^{3}$ Lecturer, Department of Anatomy, KD Dental College, Mathura, UP, India; ${ }^{4}$ Lecturer, Department of Anatomy, PDM Dental College, Bahadurgarh, India.

\section{ABSTRACT}

The spectrum of medical science is very broad and it seems to embrace almost every field of scientific study. The tools and techniques vary from as basic anthropometric measurement to as advanced as studying genes depending upon the field of medical science. Anthropometry is mainly covered under the departments of Anatomy and forensic and/or criminology units. Stature has been estimated by various researchers using arm span, hand length, length of the foot, length of fingers, demi-span, sitting height and many more. This review was aimed to study various parameters used for stature estimation and finding out the most supported one. This systematic review has included studies which have primarily focused on measurement of height with any other correlate to getting a brief account of anthropometric data on stature. The articles were sorted out using various databases which include Google Scholar, Scopus, Research Gate, PubMed and MEDLINE. All the articles were reviewed twice and most relevant articles were included and analyzed. Out of different parameters used for predicting the stature of an individual, the armspan is the most efficient and accurate. Arm span can be used for prediction of the stature of the particular population.

Key Words: Arm span, Demi span, Sitting height, Stature estimation, Hand and foot length

\section{INTRODUCTION}

Anthropometric measurement is becoming very popular nowadays in various disciplines such as in medical science, forensic science, anthropological science etc for many years. This measurement can be helpful to interpret different organ functional tests or understanding patient's states easily in medical science. ${ }^{1}$ Manmade and natural destructive events such as flooding, tsunamis, earthquakes, plane crashes, train crashes and terrorist attacks are responsible for many deaths where sometimes fragmented or dismembered humans are found. In that case, identification of the physical identity of anyone is very difficult. ${ }^{2}$ Through an anthropometric tool called stature, physical identity can be easily recognized. Anthropometric measurement includes various body parts like the length of long bones, arm span, length of the hand, foot length, demispan, etc. This in-depth study of literature aims to make a systematic review to find out reliable anthropometric dependent stature estimation variables for using different purposes. Among the parameters described, the most reliable was found to be the use of arm span for stature estimation. However, the correlation coefficient is varied for different races. ${ }^{3}$

This is a systematic review and here the literature searches were comprehensive. For searching articles, the database includes Google scholar, Scopus, Research Gate, PubMed and MEDLINE and where the keyword was anthropometry, Stature, arm span, models and related topics where the duplicates were sorted out by using Endnote X7 software for managing references. Title and abstracts were screened carefully and studies that are related to the study were included. Initially, 50 articles were selected, 15 of them were found unrelated, 11 were duplicate and 4 were not full-text hence excluded from the study. Only full-texted articles were included and otherwise excluded and disagreement was also resolved through discussions. All articles that are included in this review were checked twice by authors.

Twenty articles were finally selected for this study. These were with different anthropometric variables such as arm span, knee height, sitting height, forearm length, demi span, bi-axillary length, humeral length, hand length, thigh length, foot length, weight, standing height, half arm span,

\section{Corresponding Author:}

Pinki Rai, PhD Scholar, Department of Anatomy, SGT Medical College and Hospital, Gurugram, India. Contact: 9050675237; Email: pinkiraishkmgmc@gmail.com

ISSN: 2231-2196 (Print)

Received: 08.07.2020
ISSN: $0975-5241$ (Online)

Revised: 20.09 .2020
Published: 14.12 .2020 
leg length were examined in the estimation of stature from different previous studies and summary are given in table 1 and table 2 with details. Among all anthropometric variables, arm span is most reliable for the estimation of stature. ${ }^{1-4}$ In another study, it also found that standing height and arm span measurement were also proved to be an ideal tool for estimating the stature of individuals. ${ }^{2}$ The sitting height, standing height and arm span and leg length could be applied for the quantification of age-related decline in stature and the identification of individuals with abnormalities of growth and skeletal development. ${ }^{5-7}$ It also identified that the height to span ratio less suitable method of estimation of height than the using regression equation for the same. ${ }^{8}$ Forearm morphology helped in the estimation of stature and there was a relation between them. Some factors interfered with the anthropometric dependent stature measurement. ${ }^{3,8}$
These factors included patient's vertebral anomalies, paralysis, limb debility, and other associated conditions, but in this case, measurement of nutritional status can be possible with these type of patients., 3,9

\section{Arm-span studies}

Arm-span studies were grouped together and critically analyzed. There were varying sample sizes among these studies. Any kind of skeletal deformity was a prevalent exclusion parameter in all studies. Some of them had studied multiple parameters for comparison but the main focus was on reliability of arm span in determining the stature in that particular population. ${ }^{1,9}$ Development of the separate model for stature has also been suggested. ${ }^{10}$ The data used for analyzing literature has been summarized in the Table 1 .

Table 1: Summary of arm span data used in stature estimation.

\begin{tabular}{|c|c|c|c|c|c|}
\hline \multirow{2}{*}{$\begin{array}{l}\text { Anthropomet- } \\
\text { ric variables }\end{array}$} & \multicolumn{3}{|c|}{ Study Samples } & \multirow[t]{2}{*}{ Details in the Stature } & \multirow[t]{2}{*}{ References } \\
\hline & Size & Type & Inclusion/Exclusion criteria & & \\
\hline Arm span & 1475 & $\begin{array}{l}\text { Pulmonary } \\
\text { patients rela- } \\
\text { tives, school } \\
\text { children and } \\
\text { teachers }\end{array}$ & $\begin{array}{l}\text { Exclude: chest, spine and or } \\
\text { limb deformities }\end{array}$ & $\begin{array}{l}\text { Height estimated from arm span, } \\
\text { performs much better than arm } \\
\text { span to predict pulmonary func- } \\
\text { tion parameters }\end{array}$ & $\begin{array}{l}\text { Golshan, Amra } \\
\text { and Hoghog, } \\
\text { 2003. }^{1}\end{array}$ \\
\hline Arm span & 631 & Patients & $\begin{array}{l}\text { Exclude: aged } 15 \text { years or less, } \\
\text { structural defects, chest or up- } \\
\text { per limb deformities, Marfan's } \\
\text { syndrome, acromegaly, dwarf- } \\
\text { ism and kyphoscoliosis }\end{array}$ & $\begin{array}{l}\text { Height to span ratio less suitable } \\
\text { method of estimation of height } \\
\text { than the use of regression equa- } \\
\text { tion }\end{array}$ & $\begin{array}{l}\text { Aggarwal et al., } \\
2000^{8}\end{array}$ \\
\hline Arm span & 285 & Students & - & $\begin{array}{l}\text { Separate height models devel- } \\
\text { opment is necessity for ethnic } \\
\text { difference measurement }\end{array}$ & Bjelica et al., 2012 ${ }^{11}$ \\
\hline Arm Span & 212 & Students & $\begin{array}{l}\text { Exclusion: Body height af- } \\
\text { fected physical deformities }\end{array}$ & $\begin{array}{l}\text { Separate height models devel- } \\
\text { opment is necessity for ethnic } \\
\text { difference measurement }\end{array}$ & $\begin{array}{l}\text { Popovic et al. } \\
2016^{10}\end{array}$ \\
\hline Arm Span & 517 & Patients & $\begin{array}{l}\text { Absence of any spinal and } \\
\text { other abnormality with limbs }\end{array}$ & $\begin{array}{l}\text { Regression is the most appropri- } \\
\text { ate methods of estimating height } \\
\text { from the arm span }\end{array}$ & Chhabra. $2008^{12}$ \\
\hline Arm Span & 150 & $\begin{array}{l}\text { MBBS stu- } \\
\text { dents }\end{array}$ & - & $\begin{array}{l}\text { Reliable body parameter for } \\
\text { estimating the height of an indi- } \\
\text { vidual with high accuracy }\end{array}$ & Shah et al. $2013^{4}$ \\
\hline Arm Span & 394 & Students & $\begin{array}{l}\text { Exclude: physical deformities } \\
\text { that could affect body height } \\
\text { or arm span, and without } \\
\text { informed consent }\end{array}$ & $\begin{array}{l}\text { Separate height models devel- } \\
\text { opment is necessity for ethnic } \\
\text { difference measurement }\end{array}$ & $\begin{array}{l}\text { Popovic et al. } \\
2013^{13}\end{array}$ \\
\hline Arm span & 626 & Students & Children & $\begin{array}{l}\text { Equation dependent children } \\
\text { height estimation whom height } \\
\text { cannot be reliably measured was } \\
\text { established }\end{array}$ & $\begin{array}{l}\text { Zverev and Chisi, } \\
2005^{6}\end{array}$ \\
\hline Arm Span & 200 & $\begin{array}{l}\text { Medical } \\
\text { students }\end{array}$ & $\begin{array}{l}\text { Inclusion: } 21-23 \text { year of age } \\
\text { Exclusion: orthopaedic prob- } \\
\text { lems and metabolic disorders }\end{array}$ & $\begin{array}{l}\text { Arm span had a significant corre- } \\
\text { lation in the estimation of stature }\end{array}$ & $\begin{array}{l}\text { Mandhana et al. } \\
\mathbf{2 0 2 0}^{14}\end{array}$ \\
\hline
\end{tabular}


The majority of the studies mentioned in table: 1 favoured the efficacy of arm span in predicting stature ${ }^{1,4,12,14}$ but to use it independently as a tool was not justified. . $^{6,10,13}$

\section{Stature estimation}

The studies using multiple parameters to depict height of an individual were grouped. Critical analysis of this part of the literature was interesting and more reliable as the sample siz- es were enough to interpret the outcomes. The studies have supported the racial, gender and age-related differences in the prediction of a statute using different parameters. Among all other parameters, arm span had a comparatively more accurate estimation of stature and varied from population to population. Various parameters which were used along with arm-span are summed up in the table: 2 with details mentioned in literature.

Table 2: Summary of multiple variables that are used in stature estimation

$\begin{array}{llll}\begin{array}{l}\text { Anthropomet- } \\ \text { ric variables }\end{array} & \begin{array}{l}\text { Study Samples } \\ \text { Size }\end{array} & \begin{array}{l}\text { Type } \\ \text { Included/including } \\ \text { criteria }\end{array} \\ \begin{array}{llll}\text { Arm } \\ \text { span, knee } \\ \text { height and sit- } \\ \text { ting height }\end{array} & 110 & \begin{array}{l}55 \text { years old } \\ \text { or older }\end{array} & \begin{array}{l}\text { Include: live alone or with } \\ \text { family, healthy, were still } \\ \text { able to stand up straight } \\ \text { and to spread both arms } \\ \text { perfectly }\end{array}\end{array}$

Arm span and $\quad 1000 \quad$ Randomly Include: Ijaws and Ikwerre foot length

Forearm length 300

Height, demis- 200 pan, biaxillary length, humeral length, forearm length, hand length, thigh length, knee height and foot length

Arm span, knee 200 height and sitting height

Arm span, foot length

$\begin{array}{lcll}\text { Hand length } & 150 & \begin{array}{l}\text { Medical } \\ \text { students }\end{array} & \begin{array}{l}\text { Include: Asymptomatic, ap- } \\ \text { parently healthy, } \\ \text { adolescent and adult }\end{array} \\ \begin{array}{l}\text { Physical stat- } \\ \text { ures }\end{array} & 6,981 & \begin{array}{l}\text { Randomly } \\ \text { selected } \\ \text { individuals }\end{array} & - \\ \begin{array}{l}\text { Weight, stand- } \\ \text { ing height, arm } \\ \text { span, half arm } \\ \text { span, demi } \\ \text { span and knee } \\ \text { height }\end{array} & \begin{array}{l}\text { Out-patients, } \\ \text { staff and } \\ \text { residents }\end{array} & \begin{array}{l}\text { Include adults, elderly } \\ \text { people without limb abnor- } \\ \text { malities, kyphosis, edema or } \\ \text { dehydration, using diuretic } \\ \text { drugs. }\end{array} \\ & & & \end{array}$

people

individuals

MBBS stu- Individuals had no skeletal

dents

or pathological changes volunteers

old, amputated extrimity(s), incapability of ambulation, failure to lie down, chronic diseases such as liver cirrhosis, kidney failure, chronic use of steroid and edematous limb.

Senior citi-

Include: men and women, aged over 60 years, ablebodied, stand still and resided in Jakarta and Depok

Student

\section{Details in the Stature \\ References}

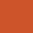

Measurement difficulties were found Fatmah, 20109

for older actual height if they had

vertebrae disorder, paralysis, disability,

and

other conditions, but nutritional

status can be measured

Racial differences were found among

individuals male vs male and female

vs female

Forearm morphology helps in the estimation of stature and there is a relation between them.

Healthy Thai Exclude: less than18 years Demi-span, sitting height, knee

height and their combination could be applied to height prediction in the adult

Ogoun et al, $2013^{15}$

Mohanty et al. $2013^{3}$

Chittawatanarat et al. $2012^{16}$

Arm span, knee height and sitting Fatmah and height can be used for assessing elders Erwin. 2012 ${ }^{17}$ nutritional status

Deviation of the height calculated us- Singh et al. ing arm span from the actual height of $2012^{5}$ were found to be less as compared to the height calculated using the foot length

Strong correlation between stature and hand length

Patel et al. $2014^{18}$

no clear relationship between reductions in height and measures Fernihough of childhood SES or childhood health \& McGovern, Standing height and arm span ideal Shahar and technique for estimating the stature of Pooy, 2003 ${ }^{2}$ individuals 
Table 2: (Continued)

\begin{tabular}{|c|c|c|c|c|c|}
\hline \multirow{2}{*}{$\begin{array}{l}\text { Anthropomet- } \\
\text { ric variables }\end{array}$} & \multicolumn{3}{|c|}{ Study Samples } & \multirow{2}{*}{ Details in the Stature } & \multirow[t]{2}{*}{ References } \\
\hline & Size & Type & $\begin{array}{l}\text { Included/including } \\
\text { criteria }\end{array}$ & & \\
\hline $\begin{array}{l}\text { Sitting height, } \\
\text { standing } \\
\text { height, arm } \\
\text { span and } \\
\text { leg length }\end{array}$ & 505 & $\begin{array}{l}\text { Randomly } \\
\text { selected } \\
\text { women }\end{array}$ & $\begin{array}{l}\text { Include: healthy } \\
\text { women in the age group of } \\
20-29\end{array}$ & $\begin{array}{l}\text { All tested variables can be used in the } \\
\text { quantification the age-related loss } \\
\text { in stature and the identification of } \\
\text { individuals with abnormal growth of } \\
\text { the skeleton. }\end{array}$ & $\begin{array}{l}\text { Mohanty et al. } \\
2001^{7}\end{array}$ \\
\hline $\begin{array}{l}\text { Height and foot } \\
\text { length }\end{array}$ & 100 & $\begin{array}{l}\text { Medical } \\
\text { students }\end{array}$ & $\begin{array}{l}\text { Inclusion: female students } \\
\text { Exclusion: skeletal deformi- } \\
\text { ties }\end{array}$ & $\begin{array}{l}\text { Regression equation derived from data } \\
\text { predicted the store very well }\end{array}$ & $\begin{array}{l}\text { Soontnoore } \\
\text { et al. } \\
2013^{20}\end{array}$ \\
\hline
\end{tabular}

Demi-span, sitting height, knee height and their combination could be applied to height prediction of adult individuals with acceptable error. In another study, it was also revealed that hand length was strongly correlated with the stature. ${ }^{18}$ It also found that separate height models development was necessary for ethnic difference measurement. ${ }^{10,11,13}$ Ogoun et al. 2013 reported that individuals with racial differences were different in anthropometric parameters too. ${ }^{15}$ Erwin \&Fatmahobserved that the arm span, knee height and sitting height can be used for assessing elder's nutritional status. ${ }^{17}$ Among all statistical methods, regression is the most appropriate method for estimation of height from the arm span. ${ }^{12}$

\section{CONCLUSION}

Recently, stature estimation is very necessary for easy identification or detection of individuals or patients in clinical and non-clinical settings. A review of various body parameters for anthropometric dependent stature estimation was the main objective of this study. Among all anthropometric variables, the arm span is more accurate and reliable variable for stature estimation, but, some authors also provided contradictory information about this statement. However, the stature varies among different populations so no standard formula can be applied to all. But for a particular population, the results are more or less similar. Moreover, according to the above discussion, anthropometry is very useful for the prediction of stature estimation but the results vary population to population.

\section{ACKNOWLEDGEMENT}

Authors acknowledge the immense help received from the scholars whose articles are cited and included in references to this manuscript. The authors are also grateful to authors/ editors/publishers of all those articles, journals and books from where the literature for this article has been reviewed and discussed.

\section{Conflict of Interest: None}

Source of Funding: None

\section{REFERENCES}

1. Golshan M, Amra B, HoghoghiM. Is arm span an accurate measure of the height to predict pulmonary function parameters? Monaldi Arch Chest Dis 2003; 59(3): 189-192.

2. Shahar S, Pooy NS. Predictive equations for estimation of stature in Malaysian elderly people. Asia Pac J Clin Nutr 2003;12(1):80- 84 .

3. Mohanty B, Agrawal D, Mishra K, Samantsinghar P, Chinara PK. Estimation of height of an individual from forearm length on the population of Eastern India. J Med Allied Sci 2013: 3(2): $72-75$.

4. Shah RK, Nirvan AB, Patel JP, Patel B. Kanani S. Estimating stature from arm span measurement in Gujarat Region. J Med Sci 2013; 2(2): 30-32.

5. Singh A, Kumar, A, Chavali K, Harish D. Use of arm-span and foot length for estimation of height of the person. J. Punjab Acad Forens Med Tox 2012;12(2): 87-91.

6. Zverev Y, ChisiJ. Estimating height from arm span measurement in Malawian children. Collegium Antropologicum 2005; 29(2): 469-473.

7. Mohanty S, Babu SS, Nair NS. The use of arm span as a predictor of height: A study of South Indian women. J Ortho Sur 2001; 9(1): 19-23.

8. Aggarwal AN, Gupta D, Mkezekiel L, Jindal SK. A statistical estimation of height from arm span in north indian subjects. Indian J Physiol Pharmacol 2000; 44(3): 329-334.

9. Fatmah. Validation of predicted height model based on arm span, knee height and sitting height in Indonesian elderly people. J Clin Med Res 2010; 2(5); 67-73.

10. Popovic S, Bjelica D, Georgiev G, Krivokapic D, Milasinovic, R. Body height and its estimation utilizing arm span measurements in Macedonian adults. Anthropologist 2016; 24 (3): 737 745 .

11. Bjelica D, Popović S, Kezunović M, Petković J, Jurak G, GrasgruberP. Body height and its estimation utilising arm span measurements in Montenegrin adults. Anthropological Notebooks 2012; 18(2):69-83.

12. Chhabra S. Using arm span to derive height: impact of three estimates of height on interpretation of spirometry. Anna Thor Med 2008; 3(3):94-99. 
13. Popovic S, Bjelica D, Molnar S, Jaksic D, Akpinar S. Body height and its estimation utilizing arm span measurements in Serbian adults. Int J Morph 2013; 31(1): 271-279.

14. Mandhana VS, Shroff GA, Ganjewar MV, Naval A. Correlation between ARM Span and Height in AgeGroup of 21-23 Years. Int J Cur Res Rev 2020;12(17);178-181.

15. Ogoun T, Fawehinmi H, Okoseimiema S. Determination of arm span and foot length between the ijaw and ikwerre ethnic group in Nigeria. Asian J Med Sci 2013; 5(6): 113-116.

16. Chittawatanarat K, Pruenglampoo S, Trakulhoon V, Ungpinitpong W, Patumanond J. Height prediction from anthropometric length parameters in Thai people. Asia Pac J Clin Nutr 2012;21(3):347- 354 .
17. Fatmah E. Developing elderly anthropometric chair (bmi meter) based on arm span, knee height, and sitting height. Int J Geomate 2016; 11(28): 2844-2850.

18. Patel JP, Patel BG, Shah RK, Bhojak NR, Desai JN. Estimation of stature from hand length in Gujarat region. J Med Sci 2014; 3(1): 41-44.

19. Fernihough A, McGovern ME. Physical stature decline and the health status of the elderly population in England. Econ Human Bio 2015; 16:30-44.

20. Deepak S, Saranabasavappa K, Prakash B, Anand M, Santosh SG, Basavaraj S. To study the determination of height by foot length in females. Int J Cur Res Rev 2013;5(16):15-19. 